\title{
PENGARUH MODEL PEMBELAJARAN INKUIRI TERBIMBING TERHADAP HASIL BELAJAR SISWAPADA MATERI POKOK SUHU DAN KALOR DI SMA NEGERI 1 RANTAU UTARA
}

\author{
Rotua Veronika Marpaung dan Makmur Sirait \\ Jurusan Fisika FMIPA Universitas Negeri Medan \\ Jalan Willem Iskandar Pasar V Medan, Sumatera Utara \\ rotuamarpaung93@gmail.com
}

\begin{abstract}
ABSTRAK
Penelitian ini bertujuan untuk mengetahui pengaruh model pembelajaran inkuiri terbimbing terhadap hasil belajar siswa pada materi pokok Suhu dan Kalor di SMA Negeri 1 Rantau Utara.Jenis penelitian ini adalah quasi eksperimen design. Populasi dalam penelitian adalah seluruh siswa kelas $\mathrm{X}$ semester IIyang terdiri dari 7 kelas yang berjumlah 280 orang. Pengambilan sampel dilakukan dengan cara cluster random sampling dengan mengambil 2 kelas yaitu kelas X-1 sebagai kelas eksperimen yang berjumlah 38 orang dan kelas X-2 sebagai kelas kontrol yang berjumlah 38 orang. Instrumen yang digunakan yaitu tes hasil belajar untuk mengetahui hasil belajar siswa.Teknik analisa data yang digunakan yaitu uji t setelah data berdistribusi normal dan homogen. Berdasarkan uji hipotesis diperoleh bahwa ada pengaruh yang signifikan penggunaan model pembelajaran inkuiri terbimbingterhadap hasil belajar siswa pada materi pokok suhu dan kalor.
\end{abstract}

Kata Kunci :model inkuiri terbimbing, hasil belajar fisika

\begin{abstract}
This studyaimed todetermine the effectof guidedlearning modelinquiryon learning outcomesof studentsin the subject matterof Temperature andHeat. This research is aquasi-experimentaldesign.Populationin thestudy were allstudents of class Xthe second halfconsists of 7classestotaling280people. Sampling wasdone byclusterrandom samplingby takingtwoclasses ofclass $X$ 1 as the experimental classnumbering38and $X-2$ as the control classthatnumbered38 people. The instrumentused is theachievement testto determinestudent learning outcomes. Data analysis techniqueused isthe $t$ testafterthe datawere normally distributedandhomogeneous. Based on thehypothesis testshowed thatthere wasa significant effectof useof guided inquirylearning modelto the learning outcomesof studentsin the subject matterof temperature andheat.
\end{abstract}

Keywords :model guided inqury, learning outcomesphysics 


\section{PENDAHULUAN}

Pendidikan merupakan suatu upaya yang dilakukan agar siswa memperoleh pengetahuan, mengembangkan intelektual serta emosional secara optimal, sehingga siswa dapat mengimplementasikan dalam kehidupan.Fungsi pendidikan adalah menyiapkan siswa agar dapat terjun ke masa yang akan datang. Strategi pelaksanan pendidikan dilakukan dalam bentuk kegiatan bimbingan, pengajaran dan latihan. Pengajaran adalah bentuk kegiatan dimana terjalin hubungan interaksi dalam proses belajar dan mengajar antara tenaga kependidikan dan siswa untuk mengembangkan prilaku sesuai dengan tujuan pendidikan (Hamalik, 2010 : 53).

Kenyataan pada saat ini bahwa pendidikan belum berjalan sesuai dengan harapan. Supardi, dkk (2010 : 72), mengatakan bahwa pendidikan di Indonesia masih terbilang rendah dan belum berhasil optimal terlebih lagi untuk pembelajaran fisika, dimana yang menjadi masalah utama pendidikan di Indonesia adalah rendahnya hasil belajar siswa disekolah. Supardi dkk (2010 : 72), rendahnya hasil belajar fisika siswa disebabkan oleh banyak hal yaitu: laboratorium yang tidak memadai, siswa kurang aktif dalam proses pembelajaran dikelas atau dengan kata lain pembelajaran dikelas masih bersifat teacher centered. Arbaiah dkk (2013 : 2), rendahnya hasil belajar siswa disebabkan oleh masih kurangnya minat siswa terhadap pelajaran fisika. Hal ini tidak terlepas dari metode yang digunakan guru saat proses pembelajaran berlangsung, dimana guru lebih sering menerapkan metode ceramah sehingga pembelajaran kurang optimal. Begitu juga lingkungan disekitar siswa apabila tidak baik maka akan berdampak pada proses dan hasil belajar.

Berdasarkan hasil studi pendahuluan di SMA Negeri 1 Rantau Utara dengan cara menyebarkan angket kepada 40 siswa kelas X diperoleh data bahwa sebanyak 30 siswa atau $75 \%$ tidak menyukai pelajaran fisika. Alasan mereka tidak menyukai pelajaran fisika dikarenakan pelajaran fisika yang membosankan dan sulit. Berdasarkan angket juga diperoleh bahwa sebanyak 25 siswa atau $62,5 \%$ siswa tidak mengulangi materi fisika diluar jam pelajaran. Kemudian ada sebanyak 38 siswa atau $95 \%$ siswa yang tidak menyukai cara mengajar guru dikelas dikarenakan guru lebih sering mengunakan metode ceramah, penugasan dan jarang dilakukan praktikum.Begitu juga dengan hasil belajar yang masih rendah. Hal ini dikarenakan proses pembelajaran lebih menekankan pada ingatan dan pemahaman materi pembelajaran, kurang dikaitkan dengan kehidupan sehari-hari. Rendahnya hasil belajar fisika didukung dari hasil wawancara denganibu Malider Damanik salah seorang guru fisika di SMA Negeri 1 Rantau Utara, 
diketahui bahwa nilai rata-rata ujian fisika siswa kelas X masih rendah jika dilihat dari nilai Kriteria Ketuntasan Minimal (KKM) yaitu 70. Pada T.P. 2014/2015 nilai rata-rata ulangan harian siswa adalah 42,5. Data ini menunjukkan bahwa nilai rata-rata ulangan harian fisika kelas X SMA Negeri 1 Rantau Utara tersebut masih tergolong rendah.Menurut Beliau pembelajaran dikelas hanya menerapkan metode ceramah, penugasan dan kadang-kadang dilakukan praktikum. Alasan guru jarang melakukan praktikum supaya materi dapat terselesaikan tepat pada waktunya, karena apabila dilaksanakan praktikum akan membuat waktu tidak efektif sehingga materi tidak selesai.

Salah satu alternatif model pembelajaran yang sesuai diterapkan adalah model pembelajaran inkuiri terbimbing.Dewi dkk (2013 : 3) model inkuiri terbimbing yaitu guru membimbing siswa melakukan kegiatan dengan memberi pertanyaan awal dan mengarahkan pada suatu diskusi dengan cara disusun secara sistematis sehingga proses belajar mengajar berlangsung secara efektif dan efesien.Menurut Kuhlthau dkk (2007 : 5)pembelajaran inkuiri terbimbing merupakan menjadi jalan dalam mempersiapkan anak-anak usia sekolah dalam abad 21. Siswa mendapatkan kompetensi dalam pembelajaran melalui penyelidikan yang di bimbing oleh pengajar pada setiap anggota kelompok.Andriani dkk (2011 : 133) pembelajaran inkuiri terbimbing yaitu suatu model pembelajaran inkuiri yang dalam pelaksanaan proses pembelajaran berlangsung guru menyediakan bimbingan atau petunjuk yang cukup luas kepada siswa. Pada saat proses pembelajaran berlangsung guru tidak melepas begitu saja kegiatankegiatan yang dilakukan oleh siswa dan memberikan pengarahan.

Penelitian ini bertujuan untuk mengetahui pengaruh model pembelajaran inkuiri terbimbing terhadap hasil belajar siswa pada materi pokok suhu dan kalor di SMA Negeri 1 Rantau Utara.

\section{METODE PENELITIAN}

Penelitian ini diadakan di SMA Negeri 1 Rantau Utara Jalan Mahoni Rantauprapatdan waktu pelaksanaannya pada Tahun Pelajaran 2014/2015 Semester II.

Populasi dalam penelitian ini adalah seluruh siswa kelas X SMA Negeri 1 Rantau Utara yang berjumlah 7 kelas dimana jumlah siswa di SMA Negeri 1 Rantau Utara seluruhnya 280 siswa.

Pada penelitian ini sampel terdiri dari dua kelas yang dipilih dengan teknik cluster random samplingyaitu kelas $\mathrm{X}_{1}$ sebagai kelas eksperimen yang menerapkan model pembelajaran inkuiri terbimbingdan kelas $\mathrm{X}_{2}$ sebagai kelas kontrol dengan menerapkan model pembelajaran konvensional.

Instrumen yang digunakan dalam penelitian ini adalah tes 
hasil belajar sebanyak 20 soal pilihan berganda dengan 5 option sebelum divalidasi. Setelah divalidasi tes hasil belajar menjadi 15 soal yang akan diberikan pada pretes dan postes.

Uji validitas yang digunakan dalam penelitian ini yaitu validitas isi dan validitas ramalan.

$$
\text { Jenis penelitian yang }
$$
digunakan dalam penelitian ini adalah quasi eksperiment.Desain penelitian yang digunakan yaitu nonequivalent control group design.seperti yang terlihat pada tabel 1 berikut ini.

Tabel 1.Nonequivalent Control Group Design.

\begin{tabular}{|l|c|c|c|}
\hline \multicolumn{1}{|c|}{ Kelas } & $\begin{array}{c}\text { Tes } \\
\text { awal } \\
\left(\mathrm{Y}_{1}\right)\end{array}$ & $\begin{array}{c}\text { Perlakuan } \\
(\mathrm{X})\end{array}$ & $\begin{array}{c}\text { Tes } \\
\text { Akhir } \\
\left(\mathrm{Y}_{2}\right)\end{array}$ \\
\hline Eksperimen & $\mathrm{Y}_{1}$ & $\mathrm{X}_{1}$ & $\mathrm{Y}_{2}$ \\
\hline Kontrol & $\mathrm{Y}_{1}$ & $\mathrm{X}_{2}$ & $\mathrm{Y}_{2}$ \\
\hline
\end{tabular}

Keterangan :

$\mathrm{X}_{1}$ : Pembelajaran menggunakan pembelajaran terbimbing pada materi pokok suhu dan kalor.

$\mathrm{X}_{2}$ : Pembelajaran dengan menggunakan model pembelajaran konvensional pada materi pokok suhu dan kalor

$\mathrm{Y}_{1}$ : Pretes diberikan pada kelas eksperimen dan kelas kontrol sebelum perlakuan. Tes yang diberikan berupa tes hasil belajar pada materi pokok suhu dan kalor.
$\mathrm{Y}_{2}$ : Postes diberikan setelah perlakuan pada kelas eksperimen dan kelas kontrol. Penelitian ini diawali dengan memberikan pretes kepada kedua kelas yang bertujuan untuk mengetahui kemampuan awal siswa.Dalam hal ini kemampuan awal siswa dapat diketahui dengan melakukan uji t dua pihak dengan syarat data harus berdistribusi normal dan homogen. Selanjutnya kedua kelas diberi perlakuan yang berbeda yaitu pada kelas eksperimen diberi perlakuan dengan menggunakan model pembelajaran inkuiri terbimbingsedangkan kelas kontrol diberi perlakuan menggunakan model pembelajaran konvensional. Setelah diberi perlakuan terhadap kedua kelas maka dilakukan postes yang bertujuan untuk mengetahui apakah ada pengaruh yang signifikan penggunaan model pembelajaran inkuiri terbimbingterhadap hasil belajar siswa. Hal ini dapat diketahui dengan cara melakukan uji t satu pihak. Dimana syarat uji t satu pihak data postes tersebut harus berdistribusi normal dan homogen.

\section{HASIL DAN PEMBAHASAN}

Berdasarkan data hasil penelitian diperoleh nilai rata-rata pretes siswa pada kelas eksperimen sebelum diberi perlakuan adalah 35,44, sedangkan dikelas kontrol diperoleh nilai rata-rata pretes adalah 33,86 . 


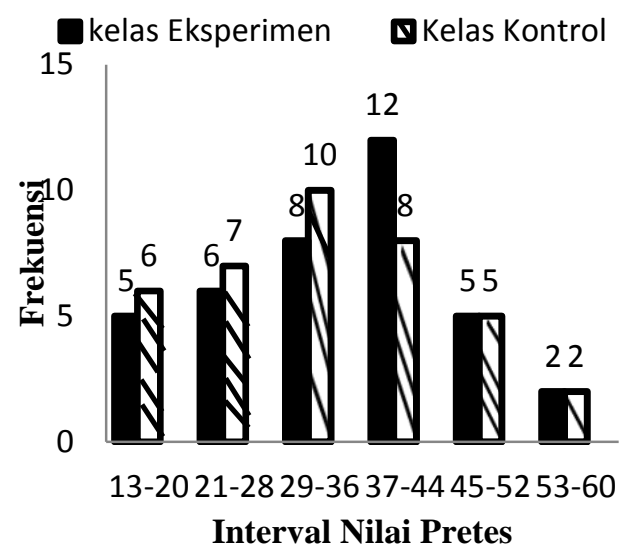

Gambar 1. Diagram Batang Nilai Pretes Kelas Eksperimen dan Kelas Kontrol

Dari gambardiatas dapat dilihat bahwa nilai pretes untuk kelas eksperimen dan kelas kontrol tidak jauh berbeda. Hal ini diketahui bahwa kemampuan awal pada kedua kelas sama.

Selanjutnya kedua kelas diberi perlakuan yang berbeda yaitu pada kelas eksperimen diberi perlakuan dengan menggunakan model pembelajaran inkuiri terbimbing sedangkan pada kelas kontrol diberi perlakuan dengan menggunakan model pembelajaran konvensional. Setelah diberikan perlakuan yang berbeda, selanjutnya kedua kelas tersebut diberikan postes dengan soal yang sama dengan pretes diperoleh hasil kelas eksperimen nilai rata-rata postes adalah 72,63 sedangkan kelas kontrol nilai rata-rata postes adalah 63,16 .

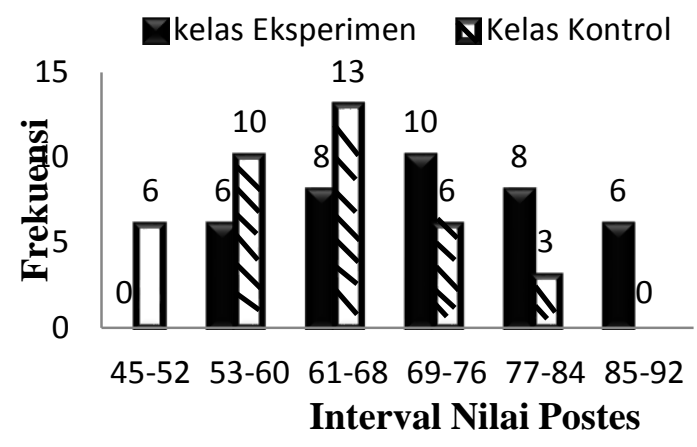

Gambar 2. Diagram Batang Nilai Postes Kelas Eksperimen dan Kelas Kontrol

Dari gambardiatas diketahui bahwa siswa di kelas eksperimen nilai nya lebih tinggi dibandingkan di kelas kontrol. Hal ini menunjukkan bahwa hasil penelitian menunjukkan bahwaAda pengaruh yang signifikan penggunaan model pembelajaran inkuiri terbimbing terhadap hasil belajar siswa pada materi pokok suhu dan kalor di kelas X semester II SMA Negeri 1 Rantau Utara T.P 2014/2015.

Hal ini didukung oleh pernyataanDeta dkk (2013 : 29) bahwa pembelajaran fisika dengan inkuiri secara signifikan lebih baik dibandingkan dengan pembelajaran yang biasa dipakai. Pembelajaran inkuiri terbimbing memiliki ciri yaitu guru hanya memberikan permasalahan tersebut melalui pengamatan, percobaan, atau prosedur penelitian untuk memperoleh jawaban. Menurut Zahara (2011 : 3) Inkuiri sebagai suatu proses umum yang dilakukan manusia untuk mencari atau memahami informasi. Inkuiri tidak 
hanya

mengembangkan kemampuan intelektual tetapi seluruh potensi yang ada, termasuk pengembangan emosional dan keterampilan. Menurut Abdi (2014 : 38) Penyelidikan terstruktur guru memberikan masukan untuk siswa dengan masalah untuk menyelidiki bersama dengan prosedur dan bahan. Jenis pembelajaran inquiry adalah digunakan untuk mengajarkan konsep tertentu, fakta atau keterampilan dan memimpin cara untuk membuka penyelidikan di mana siswa merumuskan sendiri masalah untuk menyelidiki.Menurut Suwondo dan Sri Wulandari (2013 : 216) Metode inquiry mampu menumbuhkan dasar-dasar berpikir ilmiah pada siswa, memungkinkan mereka untuk belajar sendiri bahkan selama kuliah. Ini akan menghasilkan kreativitas mereka dalam memecahkan masalah.Kuhlthau dkk (2007 : 5) pembelajaran inkuiri terbimbing merupakan jalan dalam mempersiapkan anak-anak usia sekolah dalam abad 21. Siswa mendapatkan kompetensi dalam pembelajaran melalui penyelidikan yang dibimbing pengajar dalam setiap kelompok.

Awal dari tahap ini peneliti memberikan penjelasan kepada siswa tujuan yang harus dicapai baik tujuan yang berhubungan dengan penguasaan materi maupun tujuan yang berhubungan dengan proses pembelajaran serta memotivasi siswa agar lebih aktif dalam belajar. Sulit bagi siswa untuk melaksanakan suatu tugas dengan baik apabila belum mengetahui jelas tentang apa dan mengapa melakukan suatu kegiatan atau apabila tuntutan keberhasilan belum diberitahukan secara terbuka.

Pada saat menyajikan pelajaran, peneliti memberikan pertanyaan dan siswa tertarik untuk segera mencari jawaban dari permasalahan tersebut untuk mengetahui kemampuan dasar dan melatih siswa mengajukan beberapa pertanyaan untuk pengumpulan data.

Setelah itu peneliti mengarahkan siswa untuk bekerja secara kelompok, dengan membagikan kelompok yang terdiri dari 5-6 orang dan berjumlah sebanyak 6 kelompok. Kemudian peneliti membagikan LKS dan membagikan seperangkat alat percobaan untuk masing-masing kelompok. Peneliti terlebih dahulu menjelaskan percobaan sebelum siswa melakukan kegiatan tersebut agar siswa lebih paham mengerjakan LKS.

Nilai rata-rata postes pada kelas eksperimen tergolong dalam kategori tuntas sebab belum melewati batas KKM yaitu 70 .Hasil belajar yang diperoleh dengan 24 siswa yang lulus diatas KKM dari 38 siswa dengan nilai rata-rata untuk kelas eksperimen adalah 72,63 sedangkan untuk kelas kontrol adalah 63,16 dengan data 9 siswa yang lulus diatas KKM.

Penelitian ini sejalan dengan penelitian yang dilakukan 
olehDaulay (2014 : 58), diperoleh perbedaan hasil belajar yang signifikan antara kelas kontrol yang menggunakan model pembelajaran konvensional dengan kelas eksperimen yang menggunakan model pembelajaran inkuiri terbimbing menyatakan bahwa siswa lebih aktif dengan menggunakan model pembelajaran inkuiri terbimbing dari pada dengan menggunakan model pembelajaran konvensional. Pada kelas eksperimen yang menggunakan model pembelajaran inkuiri terbimbing dapat menguntungkan karena memberi peluang yang sama kepada semua siswa, baik siswa yang memiliki kemampuan rendah, sedang maupun tinggi untuk berhasil.

Berdasarkan penelitian ini, penggunaan model pembelajaran inkuiri terbimbingdapat meningkatkan hasil belajar siswa. Selain itu masih terdapat beberapa kendala dalam melaksanakan penelitian, yaitu pada fase ketiga dan keempat dimana pada fase ketiga dan keempat siswa melakukan eksperimen dan merumuskan penjelasan, dimana pada fase tersebut siswa kurang aktif dalam berdiskusi kelompok dan lebih banyak siswa duduk diam dan menunggu hasil yang diperoleh oleh temannya daripada bergabung membantu temannya untuk memperoleh data tersebut, hal ini dikarenakan kebiasaan siswa yang belum terbiasa dalam bekerjasama dalam belajar dan menemukan sendiri jawaban dari sebuah permasalahan. Model pembelajaran ini akan lebih baik apabila siswa terlibat aktif selama proses belajar melalui kerja kelompok dan memiliki rasa ingin tahu.

Hasil belajar yang diperoleh dalam penelitian ini menggunakan alat ukur berupa tes tertulis dalam bentuk pilihan berganda. Harapan yang terkandung dalam model ini belum semuanya tercapai dengan hasil yang sangat baik, adapun faktor yang menyebabkan kondisi ini terjadi adalah masih ada siswa yang kurang aktif dan kurang tertarik dikarenakan belum terbiasa belajar dengan mengunakan model inkuiri terbimbing, sehingga butuh penyesuaian dengan siswa saat proses pembelajaran berlangsung dan pembagian siswa dalam kelompok sebaiknya berjumlah 2-3 orang tiap kelompok, dengan demikian siswa dapat bekerjasama dengan lebih efektif.

Oleh sebab itu hendaknya dalam proses pembelajaran sebaiknya siswa diajarkan dengan model pembelajaran yang lebih variatif supaya siswa mampu memahami materi pelajaranpelajaran fisika secara efektif dan efisien.

\section{KESIMPULAN DAN SARAN Kesimpulan}

Berdasarkan hasil penelitian yang diperoleh dari hasil analisa data dan pengujian hipotesis maka dapat disimpulkan bahwa ada pengaruh penggunaan model pembelajaran inkuiri terbimbing 
terhadap hasil belajar siswa pada materi pokok suhu dan kalor di kelas X semester II SMA Negeri 1 Rantau Utara T.P 2014/2015. Dimana diperoleh nilai postes dikelas eksperimen yaitu 72,63dan dikelas kontrol yaitu 63,16.

\section{Saran}

Berdasarkan kendala yang dialami peneliti selama melakukan penelitian, peneliti mengajukan saran yaitu untuk peneliti selanjutnya diharapkan dapat membagi siswa dalam kelompok lebih baik 2-3 orang dalam satu kelompok dan lebih mengoptimalkan pengelolaan kelas khususnya pada saat diskusi agar belajar mengajar menjadi efektif

\section{DAFTAR PUSTAKA}

Abdi, A., (2014), The Effect of Inquiry-based Learning Method on Students' Academic Achievement in Science Course, Universal Journal of Educational Research2: 37-41

Andriani, N., Husaini, I., dan Nurliyah, L., (2011), Efektifitas Penerapan Pembelajaran Inkuiri Terbimbing (guided inquiry) Pada Mata Pelajaran Fisika Pokok Bahasan Cahaya Di Kelas VIII SMP Negeri 2 Muara Padang, Prosiding Simposium Nasional Inovasi Pembelajaran dan Sains: 133137.

Arbaidah, Zulhelmi, dan Nor, M., (2013), Analisis Penyebab Ketidak Tuntasan Hasil
Belajar Siswa Dalam Mata Pelajaran Fisika Kelas XII Pada Ujian Nasional SMA N Pekanbaru, Jurnal: 1-9.

Daulay, L., (2014), Pengaruh Model Pembelajaran Inkuiri Terbimbing Terhadap Hasil Belajar Siswa Pada Materi Pokok Zat dan Wujudnya di Kelas VII Semester I SMP Negeri 13 Medan T.A 2013/2014., Skripsi, FMIPA, Unimed, Medan.

Deta, U.A.,Suparmi, Widha, S., (2013), Pengaruh Metode Inkuiri Terbimbing Dan Proyek, Kreativitas, Serta Keterampilan Proses Sains Terhadap Prestasi Belajar Siswa, Jurnal Pendidikan Fisika Indonesia9: 28-34.

Dewi, N.L., Dantes, N., dan Sadia, I.W., (2013), Pengaruh Model Pembelajaran Inkuiri Terbimbing Terhadap Sikap Ilmiah dan Hasil Belajar IPA, Jurnal Pendidikan Dasar 3: 110.

Hamalik, O., (2010), Proses Belajar Mengajar, Bumi Aksara, Jakarta.

Kuhlthau, C.C., Maniotes, L.K., dan Caspari, A.N., (2007), Guided Inquiry, Libraries Unlimited, London.

Supardi, U.S., Leonard, Suhendri, H., dan Rismurdiyati., (2010), Pengaruh Media Pembelajaran dan Minat Belajar terhadap Hasil Belajar 
Fisika, Jurnal Formatif2: 71-

81.

Suwondo, dan Wulandari,S., (2013), Inquiry-Based Active Learning The Enhancement Of Attitude and Understanding of the Concept of Experimental Design in Biostatics Course,Journal Canadian Center of Science and Education9: 212-219.

Zahara, L., (2011), Penerapan Pembelajaran Kontekstual Model Inkuiri Terbimbing Untuk Meningkatkan Hasil Belajar Fisika Siswa, Jurnal Educatio 6: 1-22. 